\title{
Comparison of the Use of Fly Ash dan Rice Husk Ash in the Making of Geopolymer Concrete
}

\author{
Indrayani ${ }^{1, *}$ Andi Herius ${ }^{1}$ Akhmad Mirza ${ }^{1}$ Ricky Ravsyan Alhafez ${ }^{1}$ \\ ${ }^{1}$ Civil Engineering Department, Politeknik Negeri Sriwijaya, Palembang Indonesia \\ ${ }^{*}$ Corresponding author. Email: iin indrayani@polsri.ac.id
}

\begin{abstract}
The implementation of the acceleration of development is a government program in catching up the backwardness and to improve national competitiveness, but the acceleration of development must still pay attention to environmental aspects that exist. One of the efforts in making environmentally friendly concrete materials is the use of geopolymer concrete to minimize negative impacts on the environment so that the benefits derived from the development can also be felt by future generations. Geopolymer concrete is an environmentally friendly concrete technology where the basic material of the concrete does not use cement, but uses the residual combustion of rice shells that contain a lot of silica and uses fly ash left over from burning coal. The method used in testing this geopolymer concrete uses SNI reference to several test of them aggregate testing, normal concrete compressive strength test and compressive strength of geopolymer concrete with a mixture of alkaline solution in the form of sodium hydroxide $(\mathrm{NaOH})$ and sodium silicate ( $\mathrm{Na} 2 \mathrm{SiO} 3)$ carried out at 28 days old. From the test results it was found that rice husk ash cannot be used as geopolymer concrete while fly ash can be used as geopolymer concrete in the ratio of $\mathrm{NaOH}$ to $\mathrm{Na} 2 \mathrm{SiO} 3$ at 1 : 3 and 1: 5 where at a ratio of $1: 3$ it increased $2.18 \%$ and at a ratio of $5: 1$ increased by $41.20 \%$.
\end{abstract}

Keywords: Fly Ash, Rice Husk Ash, Geopolymer, Concrete.

\section{INTRODUCTION}

Concrete is the most widely used material in construction because of the excess concrete compared to other materials, among them high compressive strength, fire resistance, corrosion resistance, and relatively cheaper. However, concrete also has a disadvantage, that is, the specific gravity of the concrete is quite high so that the calculated dead load is greater. The development carried out includes various aspects, namely the construction of buildings, roads, and bridges, where the overall development aims to be able to master the lives of many people. In line with the implementation of infrastructure development that is thoroughly carried out, of course the development must be environmentally friendly and sustainable so that the benefits derived from such development can also be felt by future generations.

Innovations on the use of environmentally friendly concrete continue to be made, for example by using material from coal combustion residues, fly ash as a substitute for cement [2][3][5]6]; comparative study of compressive strength of geopolymer concrete with conventional concrete [3]. Mixture of sodium silicate
( $\mathrm{Na} 2 \mathrm{SiO} 3)$ and sodium hydroxide $(\mathrm{NaOH})$ is used in geopolymer concrete mixes using fly ash, where in a 5 : 1 ratio, an increase in compressive strength of $40 \%$ of the normal compressive strength of the concrete [2][7]. Other studies were carried out on geopolymer concrete using husk ash, but in this study there was a decrease in compressive strength of concrete [4]. Further research on the comparison of geopolymer concrete using fly ash and rice husk ash can be carried out to obtain the percentage of comparison of the two materials for the geopolymer concrete.

From this background, a study was conducted on the comparison of the use of rice husk ash with fly ash as a substitute for cement in geopolymer manufacturing by adding alkali sodium hydroxide $(\mathrm{NaOH})$ and sodium silicate (Na2SiO3).

\section{METHODOLOGY}

The method used in this study is the laboratory testing method. This research was conducted 6 months in the Material Testing Laboratory of the Department of Civil Engineering, Politeknik Negeri Sriwijaya. 
The equipment used consists of: 1 set of material analysis tools, 1 set of sample making tools, 1 set of slump testing tools, 1 set of press testing tools. While the materials used include: sand and split taken from the village of Tanjung Raja, Ogan Komering Ilir Regency, fly ash is taken from PT. Bukit Asam, cement and rice husk ash obtained from building depots in the city of Palembang, water from PDAM. Tirta Musi which installed in the laboratory. Sodium Hydroxide $(\mathrm{NaOH})$ and Sodium Silicate Alkali Solution (Na2SiO3) was obtained from pharmaceutical chemistry.

The use of aggregate in concrete reaches $70 \%-75 \%$ of the total solid mass volume of the concrete. To achieve good concrete strength according to plan, an aggregate check is required. The aggregate examination includes: the water content testing, the sludge content testing, testing of the specific gravity and aggregate absorption. In coarse aggregate testing coupled with sieve analysis.

Tests for normal concrete and geopolymer concrete include: mixed design, slump testing, and compressive strength testing. All tests are carried out using SNI and ASTM guidelines for fly ash testing [1][8][9][10][11][12][13]. Testing of alkaline solutions, namely sodium hydroxide $(\mathrm{NaOH})$ and sodium silicate (Na2SiO3), at a ratio of $1: 1 ; 3: 1 ; 5: 1 . \mathrm{NaOH}$ solution used in this study uses $8 \mathrm{M}$ molarity levels. The

\section{RESULT AND DISCUSSION}

\subsection{Mix Design}

The results of fine aggregate analysis are 3.21\% moisture content, sludge content of $0.61 \%$, dry density 2.49 , saturated density 2.55 , absorption $2.52 \%$, loose weight $1.25 \mathrm{gr} / \mathrm{cm}^{3}$, modulus of smoothness as 3.7 , and gradation zone in zone 2 . While the results of the coarse aggregate examination are water content of $1.02 \%$, sludge content of $1.84 \%$, dry density 2.51 , saturated density 2.54 , absorption of $1.23 \%$, loose weight of $1.25 \mathrm{gr} / \mathrm{cm}^{3}$, modulus of smoothness as 7.1 . And the results of the specific gravity test are the specific gravity of cement is $1,440 \mathrm{gr} / \mathrm{cm}^{3}$, the specific gravity of fly ash is $1,915 \mathrm{gr} / \mathrm{cm}^{3}$, the specific gravity of the rice husk ash is $1.30 \mathrm{gr} / \mathrm{cm}^{3}$.

The results of the mixed design calculations are as follows: cube volume of $0.003375 \mathrm{~m}^{3}$, cement weight $1.28 \mathrm{~kg}$, sand weight $2.36 \mathrm{~kg}$, split weight $3.39 \mathrm{~kg}$, and water weight $0.69 \mathrm{~kg}$.

The composition of a mixture of normal concrete and geopolymer concrete used in this study can be seen

Table 1. Fly ash weight and rice husk ash weight are taken based on volume due to different specific gravity of each replacement material used.

Table $\mathbf{l}$. The composition of a mixture of notmal concrete and geopolymer concrete used in the study

\begin{tabular}{|c|c|c|c|c|c|c|c|c|}
\hline \multirow[b]{2}{*}{ Concrete type } & \multirow[b]{2}{*}{$\begin{array}{c}\text { Alkali } \\
\left(\mathrm{Na} \mathrm{SSiO}_{3} /\right. \\
\mathrm{NaOH})\end{array}$} & \multicolumn{7}{|c|}{ Material of normal concrete and geopolymer concrete (gram) } \\
\hline & & Cement & $\begin{array}{l}\text { Fly ash } \\
\text { andrice } \\
\text { husk ash }\end{array}$ & Water & $\mathrm{NaOH}$ & $\mathrm{Na} 2 \mathrm{SiO} 3$ & Sand & Split \\
\hline \multirow[t]{2}{*}{ Normal concrete } & 0 & 1280 & - & 700 & - & - & 2360 & 3390 \\
\hline & $1: 1$ & $=$ & 1280 & $=$ & 350 & 350 & 2360 & 3390 \\
\hline \multirow{2}{*}{$\begin{array}{l}\text { Geopolymer } \\
\text { concrete }\end{array}$} & $1: 3$ & - & 1280 & - & 175 & 525 & 2360 & 3390 \\
\hline & $1: 5$ & - & 1280 & - & 116.67 & 583.33 & 2360 & 3390 \\
\hline
\end{tabular}

solution of $\mathrm{NaOH}$ with $8 \mathrm{M}$ content was calculated using the equation:

$$
\text { Molaritas }=\frac{\mathrm{gr}}{\mathrm{Mr} \mathrm{NaOH}} \times \frac{1000}{\mathrm{~mL}}
$$

\subsection{Analysis of Normal Concrete Compressive Strength}

Table 2. N ormal Concrete Compressive Strength Test Results at Age 28 Days Testing the concrete compressive

\begin{tabular}{|c|c|c|c|c|c|c|c|}
\hline Sample & $\operatorname{Luas}\left(\mathrm{cm}^{2}\right)$ & Weight $(\mathrm{kg})$ & Load (kg) & $\begin{array}{c}\text { Compressive } \\
\text { Strength } \\
\left(\mathrm{kg} / \mathrm{cm}^{2}\right)\end{array}$ & $\begin{array}{l}\text { Average } \\
\text { Compressive } \\
\text { Strength } \\
\left(\mathrm{kg} / \mathrm{cm}^{2}\right)\end{array}$ & $\begin{array}{c}\text { Limit } \\
\left(\mathrm{kg} / \mathrm{cm}^{2}\right)\end{array}$ & Desciption \\
\hline N1 & 225 & 7.96 & 530 & 235.55 & \multirow{3}{*}{232.59} & \multirow{3}{*}{225} & \multirow{3}{*}{$\mathrm{OK}$} \\
\hline $\mathrm{N} 2$ & & & 515 & 228.88 & & & \\
\hline N3 & & & 525 & 233.33 & & & \\
\hline
\end{tabular}

Where: $\mathrm{Mr}$ is a relative molecule, atomic weight; $\mathrm{mL}$ is a milliliter; $\mathrm{Mr}$ from $\mathrm{NaOH}$ is 40 . strength by placing the specimen on a concrete press machine centrically. Emphasis is carried out until the test object is destroyed. The results of normal concrete compressive strength test can be seen in Table 2.

From Table 2 it can be seen that the average compressive strength of normal concrete is $232.59 \mathrm{~kg} /$ 
$\mathrm{cm} 2$, these results indicate that the compressive strength of normal concrete at 28 days meets the design specifications of the plan that is concrete compressive strength of $225 \mathrm{~kg} / \mathrm{cm}^{2}$.

\subsection{Comparison Analysis of Normal Concrete Compressive Strength with Geopolymers Concrete Using Fly Ash and Rice Husk Ash}

The Geopolymer concrete samples using fly ash and husk ash were made in 3 variations and tested at 28 days, while treatments for geopolymer concrete were carried out by covering the concrete with a wet sack (not soaked as is done with normal concrete). The results of compressive strength testing of geopolymer concrete at 28 days can be seen in Table 3 .

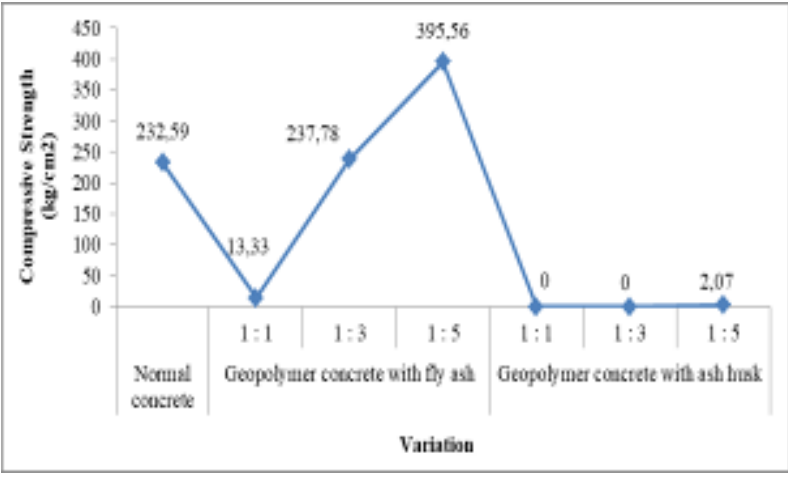

Figure 1. Comparison graph of normal concrete, geopolymer concrete with fly ash and husk ash at 28 days

Table 3. Test results for compressive strength of normal concrete, geopolymer concrete with husk ash and fly ash at 28 days

\begin{tabular}{|c|c|c|c|c|}
\hline Desciption & $\begin{array}{c}\text { Mixture } \\
(\mathrm{N} 22 \mathrm{SiO} / \mathrm{N} \approx \mathrm{OH})\end{array}$ & $\begin{array}{l}\text { Average Compressive Strength } \\
\qquad\left(\mathrm{kg} / \mathrm{cm}^{2}\right)\end{array}$ & $\begin{array}{c}\text { Limit } \\
\left(\mathrm{kg} / \mathrm{cm}^{2}\right)\end{array}$ & Information \\
\hline Normal concrete & - & 232.59 & 225 & $\mathrm{OK}$ \\
\hline \multirow{3}{*}{$\begin{array}{l}\text { Geopolymer } \\
\text { concrete with fly } \\
\text { ash }\end{array}$} & $1: 1$ & 13.33 & 225 & NO \\
\hline & $1: 3$ & 237.78 & 225 & OK \\
\hline & $1: 5$ & 395.56 & 225 & OK \\
\hline \multirow{3}{*}{$\begin{array}{l}\text { Geopolymer } \\
\text { concrete with ash } \\
\text { husk }\end{array}$} & $1: 1$ & 0 & 225 & NO \\
\hline & $1: 3$ & 0 & 225 & NO \\
\hline & $1: 5$ & 2.07 & 225 & NO \\
\hline
\end{tabular}

From table 3 it can be seen that the results of compressive strength tests of geopolymer concrete using fly ash with alkali substances at a variation of $1: 1$ are below the standard compressive strength of the plan so that it does not meet. While the compressive strength at the mixture of $3: 1$ and $5: 1$ is above the compressive strength of the plan so that it can be used as a substitute for cement in geopolymer concrete. From table 3 we can also see that the compressive strength of geopolymer concrete using husk ash in all variations of the mixture is far below the planned normal compressive strength of concrete.

Comparison graph of normal concrete, geopolymer concrete with fly ash and rice husk ash can be seen in Figure 1.
From the graph in figure 1 it can be seen that an increase in compressive strength of Geopolymer concrete using fly Ash at a ratio of 3: 1 was $2.18 \%$ and an increase of $41.20 \%$ at a ratio of $5: 1$, whereas Geopolymer concrete using rice husk ash has reduced compressive strength in all variations. This shows that husk ash cannot be used as a substitute for cement at geopolymer concrete even though it has been added with chemicals.

From the graph it can be seen that the comparison of the use of husk ash with fly ash in geopolymer concrete is very far away, where rice husk ash cannot be used as geopolymer concrete even though only as material for non-structural buildings, while fly ash can be used as a cement replacement material for structural buildings by comparison silica $\mathrm{Na} 2 \mathrm{SiO} 3$ and $\mathrm{NaOH}$ of $3: 1$ and 5:1 which have higher compressive strength than planned normal compressive strength.

From these results it can be recommended that husk ash cannot be used as geopolymer concrete because rice husk ash contains silica which is also contained in sodium silicate $(\mathrm{Na} 2 \mathrm{SiO} 3)$ so that husk ash cannot bind the aggregate in the geopolymer concrete mixture 


\section{CONCLUSIONS}

Concrete compressive strength of Geopolymers using fly Ash at a ratio of $3: 1$ and $5: 1$ is above normal concrete compressive strength, an increase of $2.18 \%$ at a ratio of $3: 1$ and an increase of $41.20 \%$ at a ratio of 5:, while the ratio of 1: 1 has decreased from normal concrete. Compressive strength of Geopolymer concrete using rice husk ash in the overall ratio is below the normal compressive strength of concrete, so that husk ash cannot be used as geopolymer concrete. Fly ash can be used as geopolymer concrete in the ratio of $\mathrm{Na} 2 \mathrm{SiO} 3: \mathrm{NaOH}$ of $3: 1$ and $5: 1$..

\section{ACKNOWLEDGMENTS}

Thank you to the Sriwijaya State Polytechnic for funding the assignment research scheme from the Sriwijaya State Polytechnic DIPA funding.

\section{REFERENCES}

[1] ASTM C618. Standard Specification for Coal Fly Ash and Raw or Calcined Natural Pozzolan for Use. Annual Book of ASTM Standards, 3-6. doi:10.1520/C0618.

[2] Indrayani, A. Herius, Mutiara, Jessica, R. Noerdin, 2019. Fly ash Sebagai Alternatif Pengganti Semen pada Beton Geopolimer Ramah Lingkungan. Prosiding Seminar Nasional Hasil Litbangyasa Industri 2, http://ejournal.kemenperin.go.id/pmbp/ view/668.

[3] M. Qomaruddin, M. Munawaroh, T.H. Sudarno, 2018. Studi Komperasi Kuat Tekan Beton Geopolimer dengan Berton Konvensional. Prosiding SNST, Vol. 1, No.1, Fakultas Teknik, Universitas Tidar, Magelang.
[4] Rihnatul, 2017. Pengaruh Penambahan Abu Sekam Padi Sebagai Pozzolan pada Binder Geopolimer Menggunakan Alkali Aktifator Sodium Silikat (Na2SiO3) Serta Sodium Hidroksida $(\mathrm{NaOH})$. Naskah Tesis, Tidak Dipublikasikan, Institut Teknologi Sepuluh Nopember.

[5] J. Satria, A. Sugiarto, Antoni, D. Hardjito, 2016. Karakteristik Beton Geopolimer Berdasarkan Variasi Waktu Pengambilan Fly Ash. Jurnal Dimensi Pramatam Teknik, Vol. 5, No. 1: 227-282.

[6] M.D.J. Sumajouw, R.S. Windah, 2014. Kuat Tekan Beton Geopolymer Berbahan Dasar Abu Terbang (Fly Ash). Jurnal Sipil Statistik, 2014, Vol. 2, No. 6: 227-282.

[7] Indrayani, A. Herius, A. Hasan, A. Mirza, 2020. The Effect of Addition of Pumice and Fiber on Compressive and Fluxural Strength Precat Lighweight Concrete. Science and Technology Indonesia, Vol. 5 No 1, DOI: https://doi.org/ 10.26554/sti.2020.5.1.14-17.

[8] SNI 03-2834-2000. Mix Design. BSNI, Jakarta

[9] SNI 1970:2008. Cara Uji Berat Jenis dan Penyerapan Air Agregat Halus, BSNI, Jakarta.

[10] SNI 03-2834-1993: Tata Cara Pembuatan Rencana Campuran Beton Normal, BSNI, Jakarta.

[11] SNI 15-2049-2004. Semen Portland. BSNI, Jakarta.

[12] SNI 03-1974-1990. Metode Pengujian Kuat Tekan Beton. BSNI, Jakarta.

[13] SNI 03-2847-2002. Tata Cara Perhitungan Struktur Beton untuk Bangunan Gedung. BSNI, Jakarta. 